\title{
JUSTIN MARTYR AND RELIGIOUS EXCLUSIVISM
}

\author{
Graham Keith
}

The Christian church developed not only from a Jewish background, but in the context of the Graeco-Roman world. This meant that Christians had to forge their identity on two fronts. They were neither Jews nor Hellenes when it came to religion; they would sometimes describe themselves as a sort of third race. 1 Whereas the Jews were accepted in the Roman world as a distinct religious group because their beliefs and practices could claim the support of a long tradition, Christians had to attempt a justification of both their novelty and exclusiveness. ${ }^{2}$

This was no academic exercise simply to convince the learned men of the time to take Christianity seriously. A profession of Christianity might involve dire consequences. From the time of the Emperor Nero Christians could be executed for no greater crime than that of being Christians. And they could remove their offence and punishment by a token act of sacrifice to a pagan god. While contemporary paganism may seem to us a hotchpotch of different cults with little in the way of supporting theology, that does not mean it was uniformly tolerant. All members of the community were expected to honour publicly those gods on whose blessing the community was thought to depend. No dissenters were allowed, as they seemed to censure the rest of the community and to jeopardise its welfare. Had Christians maintained their own religion as a private affair and been prepared to join in the local religious rites, they would have been left untroubled. But their exclusive loyalty to Christ was bound to land them in trouble. At the same time they did not want to shirk their

${ }^{1}$ Cf. A. Harnack, Die Mission und Ausbreitung des Christentums (Leipzig 19244) 1: 259-89.

${ }^{2}$ For the attitude to the Jews see the remarks of Tacitus at Histories 5:5-'hi ritus. . antiquitate defenduntur'. 
responsibilities to wider society; they had to provide a rationale for their distinctive religious outlook. ${ }^{3}$

It was no easy task for Christians to argue that they had a genuine interest in society's well-being. ${ }^{4}$ They could be dismissed as malcontents or even perverts since they believed that nothing good could be said about pagan religion. In one writer after another in this early period we find pagan religion abhorred as essentially demonic. Although not all demons were considered bad by pagans, the Christians made of this term something sinister and satanic; and in this, of course, they had good biblical precedent. 5 And yet Christians (with a few exceptions) were unwilling to be wholly negative toward that culture in which they had been brought up. If their communities had inherited pagan rites, they had also bequeathed criticisms, especially from philosophers, of that very paganism. In other words the cultural legacy was mixed. It embraced religious manifestations which were demonic, but it also contained facets which were not so obviously evil and might serve either for Christian propaganda or as a bridgehead for dialogue between pagans and Christians.

\section{Justin Martyr-Background}

One profitable approach to this issue of a mixed cultural inheritance is to consider Justin Martyr, arguably the most outstanding of the early Greek apologists. A brief biography will be of assistance. Justin was born of Greek parents in Samaria early in the second century. He showed a hankering after philosophical training, and did the rounds of a series of philosophers of the different schools. Justin felt most attracted by Platonism; but one day while he was meditating on the seashore, he met an old man who refuted his Platonism and inspired him with a longing to investigate the Hebrew prophets who predicted the coming of Christ. ${ }^{6}$ Justin was

\footnotetext{
'See further Peter Garnsey, Religious Toleration in Classical Antiquity' in Persecution and Toleration-Studies in Church History 21 W.J. Sheils (ed.) (Oxford, Blackwell 1984) 1-27.

${ }^{4}$ Cf. the remarks of R.P.C. Hanson, Studies in Christian Antiquity (Edinburgh 1985) 156-7.

${ }^{5}$ Hanson, op. cit., 164-5.

6Justin's own account of his early spiritual pilgrimage is found at Dial. c. Tryph. 2-8. It is a vexed question how far these early chapters of the
} 
converted but did not altogether relinquish his philosophical training. Thus he continued after his conversion to wear his philosopher's cloak as an indication that he had found in Christianity the true philosophy and that he was keen to defend his new-found faith in reasoned argument. Justin bears the title Martyr because he suffered martyrdom in Rome sometime between 162 and 168 . Three works of his survivetwo Apologies addressed to the pagan world of which the second may simply be an appendix to the first, and the long Dialogue with Trypho, a treatise dealing with issues of debate between the church and the synagogue.

Justin deserves special consideration because in Henry Chadwick's words-'Of all the early Christian theologians Justin is the most optimistic about the harmony of Christianity and Greek philosophy'.7 That is not to deny that Justin has his reservations about contemporary philosophy-even serious reservations. If this is the case with Justin, it will a fortiori be true of other Christian spokesmen. Nor is Justin the most knowledgeable about Greek philosophy or even the most influenced by it. That distinction belongs rather to Origen, who wrote almost two generations later than Justin. Origen, so to speak, breathes the very air of Greek philosophy. Yet, in his public statements Origen maintained a studied reserve toward philosophy. He offered it no tributes, and did not in any respect concede it superiority over Scripture. Indeed, Origen exudes complete confidence that Christianity had attained full intellectual respectability. No need remained to demonstrate parallels between Scripture and Greek philosophy. The Christian faith could stand on its own merits. ${ }^{8}$

\section{Justin and the Greek Tradition}

In Justin's time, however, there was no tradition of Christian intellectualism. Effectively he was innovative in seeking common ground between Christianity and the Greek tradition.

Dialogue are a literary fiction and how far they reflect reality. See the judicious comments of J.C.M. van Winden, An Early Christian Philosopher-Justin Martyr's Dialogue with Trypho Chapters One to Nine (Leiden 1971) 125.

${ }^{7} \mathrm{H}$. Chadwick, Early Christian Thought and the Classical Tradition (Oxford 1966) 10.

8For a brief summary of Origen's outlook see Chadwick, op. cit., 102-4. 
Actually it was not only some Greek philosophy he was prepared to commend, but other aspects of Greek literary culture. Poets and prose writers as well as philosophers might grasp some measure of truth through their possession of logos (reason) which has most supremely and completely been manifested in Christ. 9 Their grasp on truth was partial, but real nonetheless. Justin could put it like this,

'I confess that I prayed and strove with all my might that I might prove a Christian; not because Plato's teachings are contrary to Christ's but because they are not in all respects identical with them: as is the case with the doctrines of the others, the Stoics, the poets, and the prose authors. For each, through his share in the divine generative Logos, spoke well, seeing what was suited to his capacity'.10

Later Justin could boldly claim, 'whatever has been spoken aright by any man belongs to us Christians'.11 There are two ways of taking this. From one perspective Justin might be described as generous in his appraisal of non-Christian cultures since he was not dismissing them out of hand. But from another perspective, which is probably nearer to the truth, he could be seen as attempting to place Christianity on the intellectual and cultural map without much real interest in a theological assessment of other cultures.

Justin's concept of the logos, to which he attached great importance, provides a wider perspective on this issue. This logos is part of man's endowment at his creation.

'In the beginning God made the human race with the power of thought and of choosing the truth and doing right, so that all men are without excuse before God; for they have been born rational

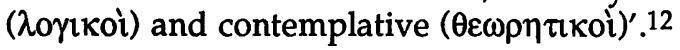

Justin does not suggest the situation has been altered in any way by original sin, a concept he either does not know or does not use theologically.

Today, the word 'rational' suggests skills in reasoning, irrespective of whether these skills are used for a right or wrong end. But with Justin logos is not reasoning in a neutral

92 Apol. 8 and 13.

102 Apol. 13-the translation here, as in other translations of Justin, is that of The Ante-Nicene Fathers Vol. 1 with a few minor changes.

11 Ibid.

121 Apol. 28. 
sense; it has important moral connotations. It entails an instinct for justice and truth, along with the wisdom to recognise these. ${ }^{13}$ Thus, Justin believed that when someone was confronted with the Christian gospel, the only reasonable response was to accept it. ${ }^{14}$ Faced with the phenomenon of the widespread persecution of Christians, Justin explained that much of it derived from prejudice and ignorance, generally instigated by demons, themselves creatures governed by irrational passions. Remove that ignorance and Justin was confident that many would readily accept the truth of Christianity. ${ }^{15}$ This was the very principle on which Justin directed his Apologies, on the surface at least, to the imperial family, who aspired to a reputation of being philosophers. He asked for a dispassionate and honest investigation of the Christians' beliefs and practices.

'Do pay close heed', Justin appealed to these rulers, 'since you are called pious and philosophers, guardians of justice and lovers of learning-and if you are indeed such, it will be made manifest. For we have come ... to ask that you pass judgement after an accurate and searching investigation, and that you be not influenced by prejudice or by a desire to please superstitious men or by irrational impulse or rumours which have long been prevalent to give a decision which will prove to be against yourselves'. ${ }^{16}$

Justin did not presume on a favourable response. He contented himself with the assertion that if the Emperor failed to accept the clear evidence, he would be inexcusable before God and would be unworthy of his reputation as a philosopher.

Clearly Justin was optimistic about the inherent powers of human reasoning which for him depend upon intuitive knowledge of what is right and wrong. Such optimism formed a basis for Justin's claims about Christians before Christ even from outside the Jewish tradition. If everyone, no matter their ethnic background, had the logos as his birthright, some must have used it aright. Justin believed he could identify examples of those who had lived in accordance with the logos

${ }^{13}$ Cf. 1 Apol. 2.

${ }^{14} 1$ Apol. 12-though Justin does qualify his position with the admission that it was not easy to alter suddenly a mind possessed by ignorance.

${ }^{15}$ Chadwick, op. cit., 13-14.

161 Apol. 2. 
and were on that account to be considered Christians. As well as citing Abraham, Elijah, Hananaiah, Azariah and Misael from Israelite tradition, Justin mentioned Socrates and Heraclitus from the Greek. ${ }^{17}$ Significantly these had all (with the possible exception of Abraham) opposed idolatry. Again, all had suffered as a result of this opposition. Justin clearly saw their situations as parallel to that of Christians in his own day. This emerges when he detailed his reasons for accepting Socrates as a Christian-notably that he had taught men to reject the demons and to become acquainted by rational investigation with the God who was unknown to them. ${ }^{18}$ Interestingly, Justin either overlooked or did not know of details contradicting his thesis. Socrates was on familiar terms with a demon of his own, and on some occasions engaged in idolatry, as when at the time of his death he arranged for a cock to be sacrificed to Asclepius. Justin's historical interpretation, then, left something to be desired. The same would apply to his later references to the Stoic philosophers, including Musonius Rufus, who suffered under the early Emperors. Justin was impressed with the Stoic moral teaching, and concluded that they had been persecuted for reasons very similar to the Christians. ${ }^{19}$ And yet these were people who lived in the Christian era, presumably in certain cases with some knowledge of Christ. Nor was Justin himself uncritical, where appropriate, of other aspects of Stoicism, notably its materialism and fatalism..$^{20}$

To return to Justin's theoretical framework, Justin argued that while some had lived with logos before Christ, others had lived without logos-by their own choice apparently. It was inevitable, he believed, that the latter should hate and persecute the former. Justin was extending Christ's teaching about the persecution of the righteous within the Jewish context to embrace not only the persecution of Christians in his own day but persecutions in other civilisations. ${ }^{21} \mathrm{He}$ was surely justified in assuming the Bible does not give a complete list of all such persecutions, but his

171 Apol. 46; cf. 1 Apol. 5 and 2 Apol. 8 and 10.

182 Apol. 10.

192 Apol. 8.

201 Apol. 43; 2 Apol. 7.

${ }^{21}$ Cf. Mt. 23:34-5; Lk. 11:49-51. 
own choice of extra-biblical examples is unfortunate. It reveals insufficient historical research, along with an unwarranted assumption that all forms of ideological persecution fitted the same mould as the persecution of Christians in his own day. At best we can say that Justin did pin-point tensions, even contradictions, within the Hellenist tradition. These tensions made a helpful springboard for Christian apologetic-and sometimes polemic for that matter. They did not adequately demonstrate the existence of true believers within that tradition. They can be explained in terms of the argument of Romans 1 . The Hellenist tradition did provide evidence against itself that it knew something of the true God but failed to acknowledge him as such.

Justin believed that every nation (not simply the Jews) has a knowledge of universal and immutable standards of righteousness. ${ }^{22}$ This need not entail that everyone adheres to that intuitive knowledge. Indeed, he suggested its main function is to render them inexcusable when they do wrong. ${ }^{23}$ He was aware too of the phenomenon of the seared conscience, which he explained as a developed rather than as a natural characteristic. ${ }^{24}$

So much would be unexceptional, but Justin is surely on shakier ground in his suggestion that the common factor in every conscience is nothing less than Christ's own summary of the whole law-You shall love the Lord your God with all your heart and with all your strength, and your neighbour as yourself'. It may be possible to say that man has an instinctive knowledge that he is to love his fellow-man as himselfthough even this is doubtful. It was a bold move, in Justin's day as in ours, to claim a universal consciousness of our duty to love God. Didn't the Greek historian Herodotus say it was absurd for anyone to say he was a friend of Zeus?

\section{Justin and the Jews}

With his stress on a revelation of God to all nations, Justin tended to undermine the special nature of God's revelation to

22Dial. c. Tryph. 93.

231 Apol. 28-presumably an allusion to Rom 1:20.

${ }^{24}$ E.H. Osborn, Justin Martyr (Tübingen 1973) 140. 
the Jews. ${ }^{25} \mathrm{He}$ could declare that the Jews did not possess significant advantages either in their knowledge of God's law or in their attainments in godliness. At one point he went as far as to issue this alarming indictment of the Jewish record-

But you (Jews) were never shown to be possessed of friendship or love either towards God, or towards the prophets, or towards yourselves, but, as is evident, you are ever found to be idolaters and murderers of righteous men, so that you laid hands even on Christ himself; and to this very day you abide in your wickedness, execrating those who prove that this man who was crucified by you is the Christ. 26

This was an extremely forthright and perhaps provocative statement, considering it emanated from the second century long before Anti-Semitism became endemic in the church.

In treating the Jewish law, Justin made distinctions, but these do not correspond to the familiar ones between the moral, ceremonial and civil laws. ${ }^{27} \mathrm{He}$ did recognise the moral law-which he described as that part of the Jewish law which they hold in common with all other races. It is his treatment of the other laws which is more controversial. He took the description given by Jesus to the law dealing with divorce, if indeed that is a law of Moses, and said that this applies across a wide range of Mosaic legislation. Most of the distinctively Jewish laws, then, were added because of the hardness of people's hearts, unless in some ways the laws were prophetic of Christ. Justin justified his position from the evident righteousness of people like Abraham, Isaac, Jacob and even Moses' mother before the law was given. They had not known the Mosaic law and had attained righteousness without it. It followed that the Mosaic law was hardly necessary for salvation. Moreover, most aspects of this law had significantly been introduced after the incident of the golden calf. God, he concluded, had to take special measures to restrain a nation who had shown themselves inveterate idolaters. Thus, Jewish

${ }^{25}$ Though the figure of Trypho is a literary fiction, modern scholars look favourably on the picture of Judaism presented in the Dial. $c$. Tryph. cf. Harold Remus, Justin Martyr's Argument with Judaism' in S.G. Wilson (ed.), Anti-Judaism in early Christianity (Wilfred Laurier, UP 1986) 2.74 .

26Dial. c. Tryph.93.

27Ibid. 44-7, cf. Osborn, op. cit., 157-8. 
phylacteries and the tassels on their outer garments were not symbols of special dedication to God, but almost the very reverse. ${ }^{28}$ Without these very obvious reminders they could not be deterred from further idolatry. Even as it was, they did not in the long run prove sufficient safeguards.

Justin's views on the Jewish law and its revelatory function were by no means untypical for the early church. It is true that some in the church took a more positive view of the law as such and simply blamed the Jews for failing to observe it, while others avoided criticism by taking an allegorical approach. But the prevailing attitude was to make the Law an unimportant section of Scripture, a temporary addition to the universal moral law which was added because of the special wickedness of the Jews. We have clearly moved a very long way from the attitude of Paul, for whom being Jewish gave an individual much advantage in the things of God, since the Jews were privileged in having 'the sonship, the glory, the covenants, the giving of the law, the worship, and the promises' as well as the patriarchs and the Messiah. 29

Justin, therefore, and many others in the Early Church did not escape a major pitfall for those who wish to extend the bounds of God's revelation outside the Judaeo-Christian tradition. They come unstuck in their treatment of God's special revelation. It is true that Justin gave pride of place to the Jewish prophets, but they are Jewish almost by accident. They were persecuted by their fellow-countrymen, while certain key elements of their teaching were divulged to leading figures in other cultures (e.g. Plato). Jewish prophets may have played a special role in the history of redemption, but the same could not be said for Jewish history.

But it would be unfair to deny that Justin did refer to the special revelation of Scripture in his belief that true believers did exist outside the Judaeo-Christian tradition. He pointed to Ezekiel 14 where God speaks of a situation in any country whose faithlessness had reached such a pitch that even Noah, Daniel or Job would not be able to do anything except salvage their own lives because of their own righteousness. ${ }^{30}$

${ }^{28}$ Dial. c. Tryph. 46; cf. 19-22.

${ }^{29}$ Rom. 9:4-5.

${ }^{30}$ Dial. c. Tryph. 44-Justin also seems to have had in mind some of the earlier heroes of faith from Heb. 11. 
But this gives only limited support to Justin's position, since these characters lived before Moses, probably even before the patriarchs. ${ }^{31}$ Indeed, it would be more consistent with the view to be enunciated by Eusebius of Caesarea that there had existed a generally recognised pre-patriarchal standard of righteousness corrupted by the Jews in Egypt and subsequently restored by Christ. ${ }^{32}$ But this is too early for Justin who wanted to recognise a post-patriarchal and post-Mosaic righteousness in many countries. In effect, he produced inadequate biblical evidence for his own thesis.

Justin directly addressed the question as to whether those Jews who were faithful in Old Testament times to the Law of Moses would be saved. He seems to have seen no difficulty about the possibility of such obedience, and was confident that such Jews would be saved. ${ }^{33} \mathrm{He}$ also stated more controversially that in his own day those who still obeyed the Law of Moses would be saved provided they believed that Jesus was the Christ and provided they did not attempt to make the Mosaic Law obligatory on others. ${ }^{34}$ But where adherence to this law was not accompanied by recognition of Jesus as the Christ, it was of no avail. Justin's analysis suggests some obvious problems. Why should obeying the Mosaic Law be sufficient at one stage in Jewish history and not at another? Justin has not satisfactorily sorted out the relationship between the law and the gospel. We are left with the suspicion that for a time at least salvation by works was acceptable with God. And that must remain-at least at the intellectual level-the position not only of Justin but of all who hold to the possibility of salvation outside a special revelation of God. For it seems impossible to talk of a gracious intervention by God without some such revelation.

31Justin's Daniel is probably the historically distant figure of Ezk. 14 rather than the better known post-exilic prophet.

32Eusebius, Demonstratio Evangelica 1:2-6 and 9:1-21.

${ }^{33}$ Dial. c. Tryph. 45.

${ }^{34}$ Ibid. 47-this was a controversial statement because Justin freely admitted other Christians were not prepared to give so charitable a verdict. 


\section{General and Special Revelation in Justin}

Justin's view that every human has implanted in him a seed of Logos, the same Logos as is perfect in Christ, raises important questions as to the relationship between general and special revelation. Justin was in no doubt about the superiority of the revelation Christians have. It is the superiority of a whole over a mere part, of the full reality over a mere copy. Justin described the partial knowledge of a person like Socrates as 'a seed of something and a copy given in proportion to the power of the receiver' ${ }^{35}$ In other words it was restricted in two ways. First, by being a seed with capacity for growth certainly, but only limited capacity. Then it was restricted by the ability of the person receiving it. The believer, by contrast, possesses 'the thing itself of which there is participation and imitation according to the grace which comes from that thing itself' ${ }^{36}$ The believer is thus directly involved with the Logos himself. He participates in the Logos and grows like the Logos. And such a relationship is possible only with grace.

Eric Osborn helpfully suggests that Justin's distinction between a pagan's and a Christian's knowledge of the truth turns on the Platonic understanding of art as a copy of a copy. ${ }^{37}$ The pagan's knowledge, therefore is genuine enough, but is two stages removed from the reality. The Christian participates in Christ who is the whole Logos and becomes the image of this Logos; whereas the pagan never has more than a seed of logos to begin with and from this forms his ov $\theta \rho \omega \pi \varepsilon i o v$

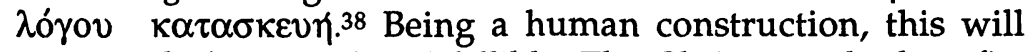
necessarily be partial and fallible. The Christian who benefits from a personal encounter with the Logos himself labours under no such limitations. One scholar has drawn this conclusion-'Knowledge of Christ and participation in his grace are therefore for Justin the constitutive elements of a direct and personal contact between Christ and Christians. This contact is essentially superior to the contact between the

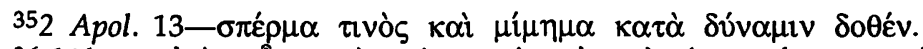

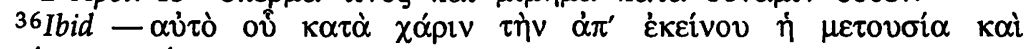

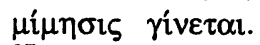

37Osborn, op. cit., 142.

382 Apol. 10. 
logos and pagans for the latter is both indirect and impersonal' ${ }^{39}$

Effectively Justin has adopted a positive attitude to pagan glimmerings of the truth, not so much to praise aspects of Hellenistic culture as to boost the status of Christian revelation. He wanted to encourage those who already highly prized the pearl of Greek culture to discover a pearl of considerably greater worth elsewhere. He was never seriously suggesting that anyone of his own day should look into Plato's teaching in order to attain salvation. He may have been prepared to say that Socrates and others from the past who lived with logos would be saved. But they were all figures from past history. Justin gave no hint that his broader hope was to be extended to people of his own day who were not professing Christians. It did not apply to unbelieving Jews, however carefully they observed the Mosaic Law. Nor did Justin believe in any category of contemporaries who had never heard the gospel and yet would be saved since they remained faithful to the light they had been given; for Justin thought every nation had in fact heard the gospel.40 This is another example of Justin's poor judgment of a situation which lay outside his immediate environment!

Justin's treatment of Christians from other cultures is thus somewhat artificial. He was not theorising about a way of salvation apart from Christ, at least for his own day, though for the past he may have been suggesting that God did work in a rather different way. In fact, considering that Justin asserted without much supporting argument that all true observations of philosophers and others really belonged to Christianity, he assumed a distinctly confrontational tone. ${ }^{41}$ It is as though he were saying-'Everything good in your tradition is first ours by right. We accept what we want from you and reject the rest; for your best men spoke only part of the truth. If you are men of reason, you will come to agree that we have the complete truth. But if you refuse to recognise this, you are behaving

${ }^{39} \mathrm{~N}$. Pycke, 'Connaissance rationnelle et connaissance de grâce chez saint Justin' Ephemerides Theologicae Lovanienses XXXVII (1961) 85. ${ }^{40}$ Dial. c. Tryph. 117.

${ }^{41}$ This point would be strengthened if we accept van Winden's view at op. cit., 113-4 that Justin endorsed Philo's idea that the Scriptures contain all philosophical knowledge. 
unreasonably and you will have to face the consequences'. It is, therefore, misleading to contrast the inclusivist Justin with the exclusivist Tertullian, as some have done. Justin was not as generous as he appears at first sight. He may have confidently asserted that Socrates, Heraclitus and others were all Christians, and this was further than he needed to go if his prime concern was to affirm that previous Gentile civilisations possessed aspects of the truth. But, as has been shown, Justin failed even here to provide the sort of evidence necessary to prove that these men were righteous in any biblical sense. And if Justin is arguably one of the most sympathetic of early Christians to the Greek tradition, he gives some idea of the limits of the patristic appraisal of pagan culture.

Justin's theory of a universal logos was not the only framework he used to explain the possession among the Greeks of important aspects of truth. He believed that philosophers such as Plato had copied from Moses. ${ }^{42}$ This was not meant as a slur, but simply to elevate the authority of Moses and others in the prophetic tradition. These prophetic writings, however, should be classed as a form of special revelation, as Justin himself made clear. Whereas philosophers might speak of God from their own opinions, prophets spoke as a result of a very different inspiration. They could pass on the ipsissima verba of God because they alone had heard and seen the truth. ${ }^{43}$ This theory of a special revelation to the Greeks, however indirectly mediated, was put alongside the notion of the spermatic logos-a theory of general revelation. Justin has left no explanation as to how the Greeks availed themselves of their intuitive logos and at the same time borrowed from Moses. These two explanations are not necessarily incompatible. Justin, however, felt no need to reconcile them. And this is evidence that in his mind, as for much of the patristic period, the distinction between general and special revelation was not systematically made. This would place further limitations on the value of any thinking about salvation outside the Judaeo-Christian tradition.

Nor was this all Justin had to say about truth within pagan settings. He did not ignore the role of the demons, in whose existence and manifold influence almost everyone of

421 Apol. 44 and 59.

${ }^{43}$ Dial. c. Tryph. 7. 
that time believed. They, according to Justin, gained knowledge of the future through the Old Testament prophecies, but determined as far as possible to throw doubt on the credibility of Christianity. They adopted a strategy of confusion by creating parallels to various prophecies within the context of pagan religions. Where Isaiah (for example) prophesied that Christ would be born of a virgin and would by his own means ascend into heaven, the demons created the legend of Perseus to whom these prophecies might be referred. Again, they produced Asclepius to duplicate Christ's role in healing every sickness and in raising the dead. ${ }^{44}$

\section{Can Greek Culture and Pagan Religion be Separated?}

As a result, Justin has produced the curious, but convenient framework whereby he could dismiss pagan religious parallels to Christianity as demonic counterfeits, whereas he welcomed parallels to the truth in every other sphere of Greek culture. Surely such a distinction is somewhat arbitrary, especially as Justin produced no argument to justify it. The wedge which Justin and others tried to drive between pagan religion and Greek philosophy rankled in the minds of certain educated pagans for whom this seemed a distortion of their tradition or even an apostasy from it.

Within 20 years of Justin a pagan Platonist called Celsus launched a vitriolic attack on Christianity which he

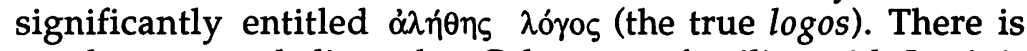
good reason to believe that Celsus was familiar with Justin's work and was reacting against it along with other manifestations of Christianity. ${ }^{45}$ In Celsus' mind pagan religion and Greek philosophy formed an indissoluble whole which could not be put asunder. To state otherwise was to reveal a gross misunderstanding of the Greek tradition, and Celsus was at heart convinced that Christians were extreme simpletons. ${ }^{46}$

If Celsus was the first publicly to expound this view of Greek culture as a single unified whole, he was not to be the last. Something of the outrage which Christian mastery of

441 Apol. 54; Dial. c. Tryph. 69.

${ }^{45}$ The most detailed treatment is by Carl Andresen, Logos und Nomos (Berlin 1955). See also Chadwick, op. cit., 132-3 n. 59.

${ }^{46}$ Chadwick, op. cit., 22-30. 
Greek philosophy could rouse among religious pagans may be evident from Porphyry's remarks about Origen, whom he knew to have been trained by the Platonist philosopher Ammonius Saccas and whom he wrongly assumed to have been brought up in a pagan environment-

Origen, a Greek educated in Greek learning, drove headlong towards barbarian recklessness; and making straight for this he hawked himself and his literary skills about; and while his manner of life was Christian and contrary to law, in his opinions about material things and the Deity he played the Greek, and introduced Greek ideas into foreign fables. ${ }^{47}$

Perhaps the most influential exponent of this link between Greek religion and culture was the Emperor Julian, famed for his short-lived pagan revival in 361-3. Julian's outlook emerges clearly from his controversial edict prohibiting Christians from teaching in schools, where they had been handling the pagan classics-

I hold that a proper education consists not in carefully acquired symmetry of phrases and language, but in a healthy condition of mind-I mean a mind that has understanding and true opinions about things good and evil, honourable and base. Therefore, when a man thinks one thing and teaches his pupils another, in my opinion he fails to educate to the extent that he fails to be an honest man. 48

Thus Julian had no truck with the view that the study of Greek literature could be a matter of form divorced from the content. His reason was the nature of the Greek classics themselves-

What! Was it not the gods themselves who revealed to Homer, Hesiod, Demosthenes, Herodotus, Thucydides, Isocrates and Lysias all their learning? Did not these men think that they were consecrated, some to Hermes, others to the Muses? I think it is absurd that men who expound the works of these writers should dishonour the gods those authors honoured ... I give them this choice: either not to teach what they do not take seriously or, if they wish to teach, to practise what they preach and to persuade their pupils that neither Homer nor Hesiod nor any of these writers whom they expound and have declared to be guilty of impiety, folly and error in regard to the gods, is such as they declare. For since they make a living and receive pay from the works of those writers,

${ }^{47}$ Eusebius, $E H$ 6: 19:7. The translation is from the Loeb edition of J.E.L. Oulton.

${ }^{48}$ Codex Theodosianus 13:3:5. 
they thereby confess that they would put up with anything ... for the sake of a few drachmas.

Julian may have paraded as the champion of the true spirit of Greek culture, but in fact his attitude was not a traditional one among pagans. It represented a fairly recent development within the Neoplatonic movement which began with Plotinus in the third century $A D$ and owed something of its systematisation to a desire to counter the growing threat of Christianity. 49 Thus Julian presents a doctrine of the divine inspiration of the leading Greek writers which seems closely modelled on Christian attitudes to the Bible, but is really foreign to Greek attitudes of (say) the fifth and fourth centuries BC. Be this as it may, Julian exposed a sore point among Christians. Many educated Christians had serious qualms about the legacy of their education. Jerome, for instance, recorded a bad dream in which he stood before the judgmentseat of Christ accused of being a Ciceronian rather than a Christian; 50 while in the east Gregory of Nazianzus in his extensive autobiographical poems revealed a tension which eventually led him to a conscious decision to throw off the rhetorical training of his youth in order to pursue his commitment to Christ. ${ }^{51}$ These were sensitive characters for whom pagan Greek culture could not be straightforwardly assessed in terms of black and white and hence posed some acute dilemmas of conscience.

There were other Christians who saw Greek culture as a more straightforward issue and dismissed it as entirely evil. One such was a pupil of Justin called Tatian, who in a work Against the Greeks began by dismissing the whole range of Greek achievements as an assortment of borrowings from various foreign nations. Greek religion was demonic through and through; and when he came to discuss Greek philosophers, far from looking for parallels with biblical teaching, he highlighted their disagreements with one another, as well as publicising any scandalous stories he could find about them. ${ }^{52}$ This entirely negative attitude to Greek culture was in the

${ }^{49} \mathrm{Cf}$. P. Athanassiadi-Fowden, Julian and Hellenism (Oxford 1981) 4-8.

50Jerome, Ep. 22:30.

${ }^{51}$ See R.R. Ruether, Gregory of Nazianzus: Rhetor and Philosopher (Oxford 1969).

52Tatian, Against the Greeks 1-3 and 25. 
fourth century to find vivid practical expression in representatives of the ascetic movement who despised all human cultural and aesthetic achievements and deliberately opted for the life of the desert over against culture and civilisation. ${ }^{53}$ Although their attitude and that of the Emperor Julian were polar opposites, they did share one common feature. Greek culture was to be accepted in toto or rejected in toto. It was all or nothing. This was not, however, to become the prevalent attitude in the Byzantine world which gradually took shape after the demise of Julian. More moderate counsels held sway like those epitomised in Basil of Caesarea's short work To Young Men, On How They Might Derive Profit from Pagan Literature. ${ }^{54}$ Here Basil stressed considerations of virtue and vice. Greek literature was valuable to the Christian insofar as it presented him with examples of virtue, but to be shunned where it detailed vicious or immoral behaviour. The predominantly moral outlook is noteworthy. Religious issuesthe danger that a reader might be infected with idolatry-were barely raised, an indication that by this time in the postConstantinian period a relapse into paganism was not viewed as a serious possibility for educated Christians.

The emerging picture might usefully be summarised in the following way. Extreme positions were taken on both the Christian and pagan sides. Some Christians effectively demonised not simply pagan religion, but the whole of Greek culture; while pagans with the directly opposite set of values turned all of classical literature into a product of divine inspiration and hence to be highly revered. And these extreme or rather totalitarian attitudes persisted for a long time. As late as the 440 's the writer Socrates Scholasticus thought fit to include a section in his Ecclesiastical History justifying Christian use of the pagan classics. Evidently, although he was writing from the cultural centre of Constantinople, he could anticipate from fellow-Christians fierce criticism of his view that Christians could read pagan works with profit. ${ }^{55}$ But most Christians who had any familiarity with pagan literature occupied a middle position in Justin's time and thereafter. It

${ }^{53}$ Athanassiadi-Fowden, op. cit., 3-4.

${ }^{54}$ Most readily accessible in vol. 4 of the Loeb edition of Basil edited by R.J. Deferrari.

55Socrates, Eccles. Hist. 3:16. 
was a position many pagans shared in broad terms. Thus, Julian's edict against Christian teachers was scathingly criticised even among people who otherwise supported his attempts to revitalise paganism. The historian Ammianus Marcellinus, for example, described it as a cruel edict which deserved to be buried in eternal silence. ${ }^{56}$ Earlier, in Justin's day a pagan Neopythagorean philosopher Numenius had gone as far as to recognise a link between the Christian Scriptures and Greek philosophy. 'What is Plato', he asked, 'but Moses in Attic Greek'?57 In this middle ground, as it might be described, debate was possible between Christian and pagan, and many Christians will have espoused it in order to facilitate interchange with their fellows in society and to prevent their becoming a marginalised group.

Even in this middle ground Christians would show no gesture of sympathy with or appreciation toward any aspect of pagan Greek cult. That remained irretrievably idolatrous or demonic. It was a different story with Greek philosophical theology, which had no obvious ties with any cults. Generally, Greek philosophers, especially those who closely followed Plato, were critical both of contemporary religious expression and of the picture of the gods as presented in the poets from Homer onwards. That is not to say these philosophers avoided idolatry in practice. Some Christians were not slow to pick up this inconsistency between philosophical theory and practice. Origen, for example, turned against the pagan Celsus a saying he himself had quoted from Heraclitus which summed up the irrational folly of idolatry-'Those who approach lifeless things as gods are like a man who holds conversation with houses'.58 The content of philosophers' work, however, remained a useful quarry of ideas for Christians like Justin and Origen. This did not seem to be undermining the Bible, since the theory that Plato and others plagiarised from Moses, however unlikely it seems to us, did forge a link between biblical and philosophical revelation..$^{59}$ In fact, Greek thought so permeated the minds of educated churchmen that they rarely, if ever, distinguished between biblical and philosophical language

56Ammianus Marcellinus, Res Gestae 22:10:7.

57Quoted in Clement Alex., Strom. 1:50:4.

58Origen, c. Cels. 1:5; 7:62.

${ }^{59}$ Cf. Chadwick, op. cit., 13-15. 
about God; while even those who proclaimed publicly their hostility to philosophy reveal a subconscious influence. 60

Interestingly, the challenge of Gnosticism provided a spur to the adaptation of philosophical theology. Irenaeus exemplified the sort of response which made little recourse to philosophy. He exposed inconsistencies in the Gnostic systems and their contradictions with the apostolic rule of faith. But when it came to their more penetrating criticisms such as Marcion raised about the character of the God of the Old Testament, he denied their right to make them, because they were going beyond the scope of Scripture, and extolled the place of a simple faith which was content to abide within Scriptural limits and leave other questions unresolved.61 Such a response, however, did not satisfy a mind like that of Origen. Simple faith might be fine for ordinary believers, but others could not rest satisfied until they attained a deeper understanding. Origen found in Platonism, which shared his antipathy to Gnosticism, a key to the problem. J.W. Trigg describes the benefit Origen derived from Platonism'Platonism, besides agreeing with Christianity on the goodness, if limitedness, of the created world and on the compatibility of God's providence with human free will, provided Origen with what Christianity manifestly lacked, a rational understanding of God's purpose in which all of these seemingly disparate and contradictory doctrines formed a coherent whole' .62 Greek philosophy, or rather part of it, had for certain Christians a positive role to play in shaping Christian theology.

It would be fair to add that some Christians viewed all borrowing from pagan philosophy with suspicion. This is perhaps not surprising since the one biblical reference to philosophy by name is hostile, if it is read apart from its full context.63 Thus, Hippolytus, a Roman theologian and an older contemporary of Origen, treated philosophy as a breeding-

${ }^{60} \mathrm{Cf}$. the interesting comments of Hanson, op. cit., 246-9 on how the Arian Controversy forced churchmen to grapple with philosophical issues.

${ }^{61} \mathrm{J.W}$. Trigg, Origen-The Bible and Philosophy in the Third-century Church (London, SCM 1985) 50-1

62Trigg, op. cit., 73.

${ }^{63} \mathrm{Col}$. 2:8-'See to it that no-one makes a prey of you by philosophy and empty deceit'. 
ground for error, and tried to demonstrate that each significant heresy could be analysed as the adaptation of one particular philosophical strand.64 This outlook was revived in the later part of the fourth century by Epiphanius and others who complained that some of the later manifestations of Arianism were simply Aristotelian philosophy in disguise. 65 Epiphanius also launched a lengthy and direct attack on Origen for various heresies; he explained that Origen had been blinded by Greek culture.66 Even in his own day Origen's work had been regarded with suspicion in some quarters. Perhaps it was inevitable that after the embittered Arian Controversy, to which Origen was thought to have made a considerable indirect contribution, his legacy should have been the subject of increased suspicion. Nor was this suspicion confined to isolated doctrines; it extended to Origen's whole theological method. How valid had it been for him to try to build Christian doctrine with tools largely borrowed from Greek philosophy?67

The same broad issue is still with the church, but one significant handicap has been removed. Today few consider philosophy as an ideology or as a way of life in its own right. Some in the classical world evidently did think in this way. Philosophy could exercise a fascination over younger minds similar to that of Communism, Existentialism or the CounterCulture in this century. ${ }^{68}$ By contrast, modern practitioners claim only a secondary role for philosophy-e.g. 'philosophy is not a subject which has its own autonomous subject-matter, as does astronomy, biochemistry, English literature or international law. It is an ancillary discipline which examines the ideas, truth-claims and methods practised in a discipline, and seeks to elucidate and evaluate their nature' ${ }^{\prime} 69$ In discussions of pluralism recourse to philosophy, especially epistemology, cannot easily be shirked. Proponents of any form of religious exclusivism have, after all, to answer the

${ }^{64}$ Chadwick, op. cit., 8.

${ }^{65}$ Epiphanius, Pan. 76:2:2-3.

66Ibid. 64:72:9.

${ }^{67}$ See the discussion of Chadwick, op. cit., 95-123.

${ }^{68}$ Cf. S. Dixon, The Roman Mother (London \& Sydney 1988) 171.

${ }^{69} \mathrm{This}$ definition is taken from the article 'Philosophical Theology' in New Dictionary of Theology S.B. Ferguson \& D.F. Wright (edd.) (Leicester, IVP 1988). J. Hick in Philosophy of Religion (Prentice-Hall 19834) 1-2 makes a similar point. 
challenge 'How do you know you are right?' Nor can Christians hope to convince outsiders by appealing to the ministry and authority of the Holy Spirit, important as these may be in their own experience. They have to embrace philosophical arguments to show the reasonableness of their position. The Apologists like Justin were convinced they could demonstrate the reasonableness of Christianity to the pagan world of their own day. They may have been over-confident about the unaided powers of human reason, but we can imitate their confidence that the exclusive truth of Christianity will surmount all the philosophical challenges of our day.

\section{Justin and the Contemporary Debate}

While we may smile at Justin's facile distinction between Greek religion as demonic and Greek literary culture as a mixture of good and evil, Justin was surely justified in making some distinction between the specifically religious and the purely cultural. It may not be possible to draw the dividing line as sharply as Justin did; the reality is bound to be more complex. But Justin's contribution was to affirm clearly that Greek culture was so diverse that it ought neither to be accepted in toto, as some pagans like the Emperor Julian wanted, nor rejected in toto, as Christians like Tatian wanted.

Moreover, Justin did go some way along the line of exploiting tensions or contradictions within the Greek cultural tradition. Socrates, for example, whom everyone honoured, was upheld by Justin as a prize 'atheist', in the sense that he rejected contemporary idolatry. ${ }^{70}$ But Justin took a bolder and more fundamental step when he endeavoured to re-define philosophy, a concept dear to himself as well as many Greeks. ${ }^{71}$ For he was convinced that contemporary philosophy, for all its pretensions to grasping reality and even in some cases to attaining the knowledge of God, had failed to attain its goal. Its failure was evidenced in the various competing philosophical schools when there could be only one objective truth. But this had not originally been the case. True philosophy had been a divine gift sent down into the world of men. Its early practitioners had begun to make good use of it,

701 Apol. 5-6.

${ }^{71}$ Cf. Osborn, op. cit., 99-110. 
but their successors had not initiated any further investigations of their own. Instead, they were content uncritically to rehash the findings of their first masters. Thus they developed schools which were named after the originators of their distinctive doctrines. But Justin would not concede that any of these schools were entitled to be called philosophers. ${ }^{72}$

Justin's analysis of the history of philosophy was paralleled in his outlook on the various sects and heresies which had emerged from Christianity and had claimed its name. ${ }^{73}$ Again, the original revelation was sound and was presumably maintained among orthodox Christians, while heretics had passed on the partial truths and sometimes patent lies of certain individuals as the whole truth. This was simply a recent variation on an old demonic trick of confusing the truth.

Clearly Justin has sketched out a theory of general divine revelation, which is not developed in detail in his extant works. This is not the place to give his view a thorough analysis other than to commend him for discerning an historical dimension to man's response to God's revelation. This provided a framework to support Christianity's exclusiveness and novelty, since it implied that Christianity was not so new as it appeared and that factors had long been at work to confuse and blind human religious instincts. In a pluralistic climate like that of today it is incumbent on Christians to offer an explanation at least of some nonChristian traditions. Few will want slavishly to follow Justin; he does, however, alert us to the danger of drawing farreaching conclusions from limited historical data without a full context. Indeed, when it comes to the emergence as distinct from the maintenance of religious traditions, vital historical evidence is often lacking and may well in the nature of things be impossible to attain. Our best clues about the genesis of non-Christian religions perhaps remain the testimony of Scripture, especially Romans 1 and the Old Testament tradition on which it is based. The Scriptural approach would not lean quite as heavily as Justin does on the demons, who in his hands almost become powers beyond God's control; but

${ }^{72}$ Van Winden, op. cit., 42-5.

${ }^{73}$ Justin had himself written a work, now lost, about all the heresies which had arisen by his time, 1 Apol. 26. 
would make fuller use of the category of divine judgment in giving men over to spiritual blindness. ${ }^{74}$

In his own day Justin did fulfil a useful role in stressing the demonic. This cannot be dismissed as an easy device to cope with the uncomfortable reality of widespread opposition to Christianity. Justin was highlighting one of the deepest fears of a society where Christian and pagan alike believed in demons, even in evil demons. Pagans certainly held that there were some good demons as well as evil ones; Christians differed in their insistence that all demons were evil. The area of agreement was, however, considerable. Christians could simply represent themselves as boldly drawing conclusions pagans might suspect in their heart of hearts to be true. ${ }^{75}$ Justin may have detailed certain demonic strategies-through dreams, through magic, through pagan religion (particularly he had in mind sacrifices to idols), through myths and most recently through the spreading of heresies.76 But this was not an area where precise argument was felt necessary. After all, Christians knew they were dealing with matters of common experience, not mere intellectual notions. They had no problems in accepting the apostle Paul's assertion that pagans offered sacrifices to demons and so were involved in fellowship with them.77

It was the character and activity of demons which justified Christian exclusiveness at both practical and theoretical levels. If pagan religious practices invariably brought contact with demons, Christians had an excellent reason for abstaining. Furthermore, when Justin contended that Christ was destroying Satan, the prince of demons, he could imply that the greatest possible service was being performed to the human race. Far from being a negative

${ }^{74}$ Of course, passages like 1 Tim. 4:1f. and 1 Jn 4:1f. do indicate that demons play a part in heretical teaching. But interestingly Paul does not resort to the demonic in his analysis in Rom. 1 of Gentile attitudes to God. Even at 2 Thes. 2, where Paul describes the satanic impulse to the coming of the man of lawlessness, he makes it clear that those who will be deceived are being punished by God for their rejection of the truth.

${ }^{75} \mathrm{Cf}$. R. Lane Fox, Pagans and Christians (Harmondsworth 1986) 326-30.

76 Osborn, op. cit., 58-60.

771 Cor. 10:20. 
influence in society, Christianity had highlighted one of man's greatest problems and provided a solution to it. 78

Justin, therefore, was no exception to the exclusivism of mainline Christians of this period. ${ }^{79}$ But his was an exclusivism which did not prevent him either from building bridges with pagan culture or from seeing some work of God outside the Judaeo-Christian tradition. (Indeed, as has been shown, he underplayed the role of the Jews in God's plan of revelation and salvation.) His achievement lay in arguing not only that Christianity fulfilled all that was good in Greek philosophy but that it was also much superior to that philosophy. Few in the early church managed to make both these points so clearly. A similar challenge confronts the church today. This would apply not only in the Third World, where many Christians, lately emerged from idolatry, are involved in the vital task of cultural evaluation, but in the Western World where the breakdown of Christendom has seen the emergence of as bewildering a variety of philosophical options as those offered by Greek philosophy within the Roman Empire.

${ }^{78}$ Cf. Dial. c. Tryph. 45 and 100.

${ }^{79}$ Unfortunately, H.A. Netland makes this mistake in his fascinating book Dissonant Voices-Religious Pluralism and the Question of Truth (Leicester, Apollos 1991) 12-3. It is very difficult, if not impossible, to find anticipations among early Christians to modern views of religious relativism. 